\title{
A SURVEY OF SPORT PLAYED IN THE ARMY
}

\author{
S. ROSENBAUM, M.A., Ph.D.*
}

\section{Introduction}

Injuries at sport constitute an important part of the manpower wastage due to all forms of injury in the Army. This was a primary reason for conducting the present survey. But it was obvious that the results of a survey would also be of value in formulating physical training policies, and in determining requirements for equipment and facilities such as sports grounds. Given sufficient detail, the effect of factors such as age, rank and physique could be assessed.

It is possible to analyse the causes of those injuries which lead to admission to an Army Hospital or other medical unit through the entries made on clinical records, which are subsequently transferred to punched cards. Not only is it possible to determine how large an element is due to sport, but also to see for instance, that football is responsible for the largest proportion of sports injuries and how serious they are. The further step of comparing the relative dangers of different sports can only be taken by discovering the extent to which they are played; once the numbers at risk are known, the task of computing the incidence rates is a simple one.

It was for these reasons that a sample survey was carried out, and the results are given in Part 2 of this paper. The remainder of the paper discusses the injuries and relates them to the amount of sport played.

\section{Sample Survey of Sport}

\section{2a. Method and response}

It was decided to select a random sample of the whole Army each month during the year 1962, and to ask each man to keep a diary of his sports activities throughout the month; the monthly sampling fraction was 2 per 1,000 soldiers. The instructions asked for the number of minutes spent each day on each sport to be entered in the diary. Intervals of play were to be included, but not time spent changing, and travelling to and from the game.

Sports which were offered by the diarists were many in number and ranged from angling to volley-ball. It was difficult to decide where to draw the line at admitting any particular form of recreation, such as darts, or table-tennis when analysing the results, and if these were excluded among others, it was not because they were judged not to be healthful occupations (or indeed devoid of danger) but rather because few diarists would have considered putting them down. It was found after a while that about a quarter of the diaries were not coming back, and so those who failed to respond in the last 3 months of 1962 were followed up in search of an explanation. A common reason was that many were on the point of leaving the Army in this last year of National Service. Other reasons varied from being on active service to forgetfulness.

The total numbers who played should be increased by perhaps a third to arrive at an estimate for the whole Army, though this assumes that the non-responders played as much. There is no evidence that the relative amounts of different sports played will have been affected:

*Formerly of A,M,D,(Stats). 
2b. The amount of sport played.

The number of diaries returned was 3,185 , and of these 2,358 reported that the diarist had played some form of sport during the month. The remainder did not necessarily always refrain from playing - no information was gathered about playing habits throughout the year.

The number of days on which the 2,358 players played was 24,655 , an average of 10.46 days in the month.

Individuals most often played once or twice a week, but almost one in four played more frequently than every other day; not a few played every single day.

Since two sports could be played on one day, the number of sports periods exceeded the number of days, and amounted to 30,157 periods. Many players went in for more than one type of sport during the course of the month, the average being 2.76 per player. Each sport was played for an average of 4.63 periods.

\section{2c. The types of sport: the effect of rank and age}

The relative amounts of each sport played may be judged either by the number of players, in which case association football was the most popular, or by the number of periods played, in which case physical training (P.T.) was, at any rate, most common. Table 1 shows the most important numerically, in order of the number of players.

Recalling that 2,358 people were involved, one can say, for instance, that almost half of them played association football in an average month.

Table 1

Number of players at each sport, and periods played

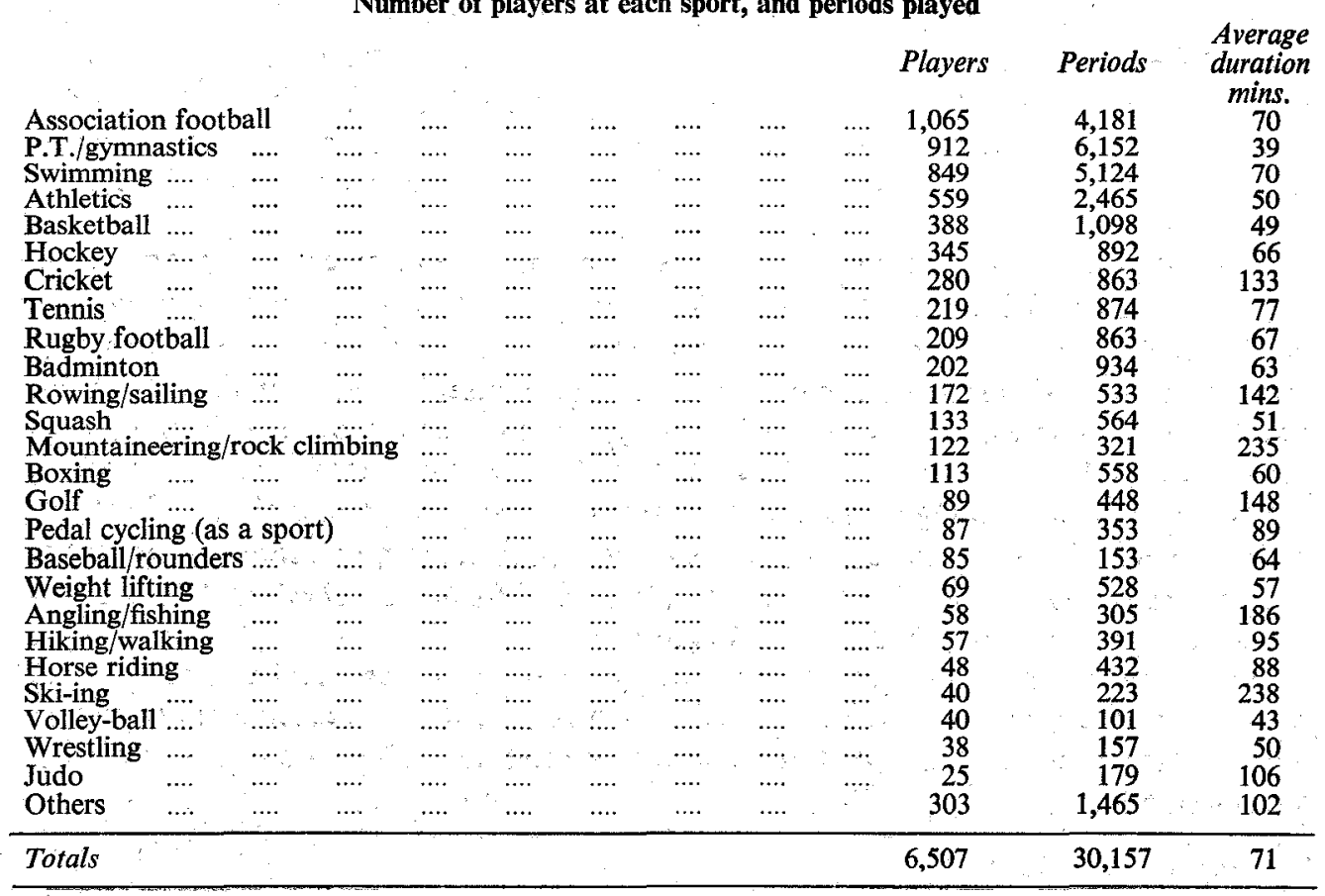


The differences in the types of sport played by officers, which have their roots in the schools they attended, are illustrated in Table 2. For example soldiers preferred to play soccer and officers rugger, though officers were more evenly balanced between the two codes. Officers also played squash and golf more.

Table 2

Percentages in each age group who played particular sports

\begin{tabular}{|c|c|c|c|c|c|c|c|c|}
\hline & & Age & less than 17 & $17-$ & $20-$ & $25-$ & $30-$ & $40-$ \\
\hline Association football & $\begin{array}{l}\text { Othcers } \\
\text { Soldiers }\end{array}$ & & 61 & 57 & $\begin{array}{l}17 \\
56\end{array}$ & $\begin{array}{l}10 \\
47\end{array}$ & $\begin{array}{r}1 \\
28\end{array}$ & 32 \\
\hline P.T. & Officers & & & & 38 & 15 & 9 & 15 \\
\hline Cuniming & Soldiers & & 84 & 58 & 41 & 34 & 26 & 23 \\
\hline Swimming & $\begin{array}{l}\text { Officers } \\
\text { Soldiers }\end{array}$ & & 36 & $\Delta 1$ & 17 & $\begin{array}{l}35 \\
35\end{array}$ & 26 & 36 \\
\hline Athletics & Officers & & 30 & 41 & 23 & 27 & 9 & 6 \\
\hline & Soldiers & & $49^{-}$ & 40 & 24 & 20 & 14 & 9 \\
\hline Cricket & Officers & & & & 23 & 23 & 6 & 11 \\
\hline & Soldiers & & 16 & 12 & 12 & 12 & 10 & 11 \\
\hline Rugby football & $\begin{array}{l}\text { Officers } \\
\text { Soldiers }\end{array}$ & & 22 & 12 & $\begin{array}{r}23 \\
9\end{array}$ & $\begin{array}{r}19 \\
8\end{array}$ & $\begin{array}{l}8 \\
3\end{array}$ & $\begin{array}{l}1 \\
1\end{array}$ \\
\hline Squash & Officers & & & & 54 & 19 & 24 & 13 \\
\hline & Soldiers & & 0 & 4 & & 3 & 5 & 1 \\
\hline Golf & Officers & & & & 8 & 15 & 20 & 26 \\
\hline & Soldiers & & 1 & 0 & 1 & 2 & 3 & 12 \\
\hline Total numbers playing & $\begin{array}{l}\text { Officers } \\
\text { Soldiers }\end{array}$ & 二 & 67 & $\begin{array}{r}1 \\
362\end{array}$ & $\begin{array}{r}52 \\
965\end{array}$ & $\begin{array}{r}52 \\
318\end{array}$ & $\begin{array}{r}89 \\
272\end{array}$ & $\begin{array}{r}105 \\
75\end{array}$ \\
\hline
\end{tabular}

One must distinguish in the age analysis between the percentage of diarists participating in sports, which fell to something over half of those older than forty, and the percentage of sportsmen given in Table 2 who played particular games. Thus the percentage of swimmers among the soldiers declined with age, even though it remained a popular outlet for those who took part in sports. The popularity of golf increased on both counts.

\section{2d. Variation according to season and climate}

Table 3 shows the amount of sport played each month, adjusted to a standard length of $30 \frac{1}{2}$ days.

Table 3

Average days of sport per player: adjusted to month of $30 \mathrm{t}$ days

$\begin{array}{lcccc} & \text { All theatres } & \text { U.K. } & \text { BAOR } & \text { Other theatres } \\ \text { January } & 10.4 & 9.2 & 10.1 & 13.1 \\ \text { February } & 10.2 & 9.9 & 8.7 & 1.7 \\ \text { March } & 10.5 & 10.3 & 9.2 & 1.1 \\ \text { April } & 9.3 & 9.0 & 8.5 & 10.9 \\ \text { May } & 11.5 & 12.4 & 8.1 & 13.1 \\ \text { June } & 11.2 & 11.0 & 9.6 & 14.2 \\ \text { July } & 11.6 & 10.7 & 10.7 & 14.6 \\ \text { August } & 11.5 & 10.1 & 11.1 & 15.2 \\ \text { September } & 9.8 & 9.8 & 7.4 & 12.5 \\ \text { October } & 11.1 & 12.4 & 8.6 & 11.9 \\ \text { November } & 10.3 & 10.2 & 8.2 & 14.0 \\ \text { December } & 8.1 & 6.5 & 9.9 & 9.6\end{array}$

December, the month with the lowest average, included the Christmas holiday of course; also, April that year included Easter. September is often a month of military 
exercises and manoeuvres. These special circumstances aside, there appears to have been slightly more participation in sport during the summer months.

The players in the U.K. and BAOR are seen to have played on fewer days throughout the year than in other theatres; there was also a slightly lower average in BAOR than in U.K., in most months.

The amount of sport played also varied with the day of the week, particularly in this country and in BAOR. Wednesday was the most popular day for games almost everywhere. Sunday was the least popular in the United Kingdom and BAOR, but not elsewhere.

The difference between theatres as regards the popularity of individual sports can be seen in Table 4.

Table 4

Percentages in each theatre of the periods devoted to each sport

\begin{tabular}{lccccc} 
& U.K. & BAOR & Near East & Middle East & Far East \\
Association football & 14.2 & 16.4 & 7.4 & 14.9 & 11.4 \\
P.T. & 24.9 & 20.3 & 8.3 & 13.4 & 12.9 \\
Swimming & 11.1 & 8.9 & 36.8 & 42.7 & 33.5 \\
Athletics & 9.2 & 9.2 & 9.2 & 3.2 & 4.1 \\
Basketball & 3.4 & 4.8 & 2.7 & 2.5 & 3.8 \\
Hockey & 2.7 & 3.6 & 3.2 & 2.9 & 2.8 \\
Cricket & 3.2 & 3.3 & 3.3 & & 2.3 \\
Tennis & 2.5 & 3.3 & 6.0 & & 7.8 \\
Rugby football & 3.4 & 3.3 & 2.9 & & 2,887 \\
Badminton & 2.3 & 3.8 & & & 1,414 \\
\hline Total periods & 14,451 & 7,428 & 1,873 & & \\
\hline
\end{tabular}

Some of the divergencies are due to the lack of facilities in certain places, such as for example tennis courts and cricket pitches. But differences in climate must be the major determining factor. In particular swimming accounted for about a third of the periods in the warm latitudes. P.T. was highest in the U.K., where there was a preponderance of young soldiers under training.

In each theatre, the length of the season was important in determining the quantity played of a particular kind of sport, for instance there is an obvious limit to the length of the cricket season in this country.

Association football was played a great deal throughout the year in this country and in BAOR. In the United Kingdom it involved about half of all sports players, except in June and July; in BAOR the proportion was generally as high, and did not drop below about a third, even in summer. In warmer climates football was also played throughout the year, with scarcely less frequency, even in the hottest months. Swimming, at the peak of its season in this country involved practically half of the sportsmen. Even in the winter about one in seven went swimming. Of course, in more sultry climates the swimming season lasts the year round, though there may be some distinction still between winter and summer.

\section{2e. The physique of players}

Apart from schooling, " natural ability" together with inclination and opportunity determines what a player goes in for. Natural ability is partly a matter of physique and 
Tanner (1964) among others has succeeded in classifying athletes according to their degree of mesomorphy etc. However, his subjects were athletes who excelled at their chosen sport, whereas the present survey is just a cross-section of ordinary players. Detailed measurements were not available for the assessment of somatotypes, but height and weight could be established in most cases from the record of their medical examination as recruits, their present age being thereby discounted. The method is, of course, crude in that it lumps together sprinters and steeplechasers, wing three-quarters and second row forwards, featherweights and heavyweights. Table 5 shows average heights and weights of soldiers only, because officers are taller and heavier, and their inclusion would blur the comparisons.

Table 5

Average heights and weights (as recruits) of soldiers playing each sport

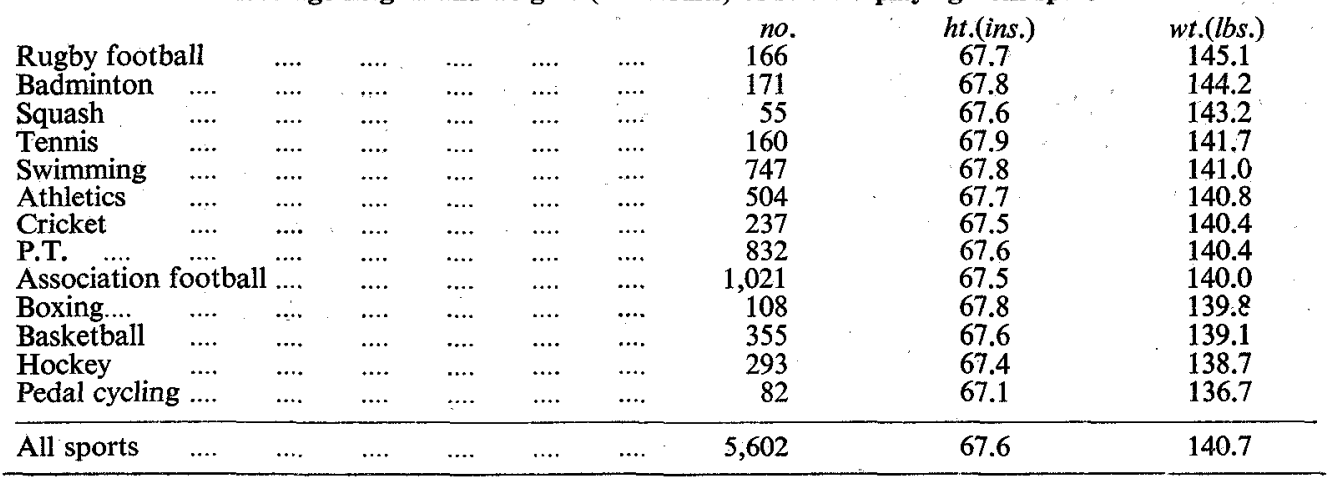

\section{2f. Energy expenditure}

The energy expended by the average soldier (of the order of 3,000 kilocalories daily) is of concern, not least in determining the proper size of the Army ration. The part attributable to sport could be an important factor in the energy balance of an individual soldier, and it might also be a significant element for the whole Army. We attempt here to estimate the size of this factor from the results of the present survey and from energy costs for individual sports that have been estimated in the past, as for example, by Passmore and Durnin (1955), and Edholm et al. (1955).

From Table 1 one can deduce the average number of minutes spent daily on each sport per player, and per diarist (since calorie needs for the whole population of soldiers are met by an overall assessment of the rations required, including those of non-players). In total, the figure comes to 29.8 minutes per player, or 22.1 minutes per diarist daily, as shown in Table 6.

The energy expenditure of a number of these has been investigated (see refs. above), and an indication is given of the values found. The range of determinations in each case was very great, for instance association football was estimated at values from $6 \mathrm{kcal} . / \mathrm{min}$ to $12 \mathrm{kcal} . / \mathrm{min}$. Also the estimates for different sports were culled from a variety of sources.

The 17.4 minutes for which the estimates above are quoted account for $127.1 \mathrm{kcal}$. for the average player, averaging about $7 \mathrm{kcal}$. per minute; but many of the estimates 
Table 6

\begin{tabular}{|c|c|c|c|c|c|c|c|c|c|}
\hline $\mathbf{P} \mathbf{T}$ & & & & & & & $\begin{array}{l}\text { Average } \\
\text { player } \\
\text { daily }\end{array}$ & $\begin{array}{l}\text { Average } \\
\text { diarist } \\
\text { daily }\end{array}$ & $\begin{array}{l}\text { Estimated } \\
\text { kcal./min }\end{array}$ \\
\hline P.T. & .... & $\cdots$ & $\cdots$ & .... & $\cdots$ & $\cdots$. & $3.3 \mathrm{mins}$ & $2.5 \mathrm{mins}$ & \\
\hline $\begin{array}{l}\text { Basketball } \\
\text { Athletics }\end{array}$ & $\cdots$. & $\cdots$ & $\cdots$ & $\cdots \cdot$ & $\ldots$. & $\cdots$ & $\begin{array}{l}0.8 \\
1.7\end{array}$ & $\begin{array}{l}0.6 \\
1.3\end{array}$ & \\
\hline Badminton & $\ldots$ & $\ldots$ & $\ldots$ & $\ldots$ & $\ldots .$. & .... & 0.8 & 0.6 & \\
\hline Hockey & $\ldots$ & $\ldots$. & .... & $\cdots$ & $\ldots$ & $\ldots$ & 0.8 & 0.6 & \\
\hline Rugby footba & all & $\cdots$ & $\ldots$. & $\ldots$ & $\ldots$ & .... & 0.8 & 0.6 & \\
\hline Association fo & ootball & L.... & $\ldots$ & $\ldots$ & $\ldots . .$. & $\ldots$. & 4.1 & 3.0 & 9 \\
\hline Swimming & $\ldots$. & $\ldots$. & $\ldots$ & $\ldots$ & .... & $\ldots$ & 5.0 & 3.7 & 8 \\
\hline Tennis & .... & $\ldots$ & $\ldots$ & $\ldots$. & $\ldots$ & .... & 0.9 & 0.7 & 7 \\
\hline icket & .... & $\ldots$ & $\ldots$. & .... & $\ldots$ & $\ldots$ & 1.6 & 1.2 & 5 \\
\hline & $\ldots$ & ... & $\cdots$ & .... & $\ldots$ & .... & 0.9 & 0.7 & 5 \\
\hline Boxing & $\ldots$ & $\ldots$ & $\ldots$. & $\ldots$ & $\ldots$ & .... & 0.5 & 0.3 & \\
\hline Mountaineerir & ing & $\ldots$ & $\ldots$ & $\ldots$ & $\ldots$ & $\ldots$ & 1.0 & 0.8 & \\
\hline Sc & $\ldots$. & $\ldots$ & $\ldots$ & $\ldots$. & .... & ..... & 0.4 & 0.3 & 10 \\
\hline iking & $\ldots$ & $\ldots$ & $\ldots$ & $\ldots$ & $\ldots$ & $\ldots$ & 0.5 & 0.4 & $5 \frac{1}{2}$ \\
\hline Ski-ing.... & $\ldots$. & ..... & $\ldots$ & $\ldots$ & $\ldots$ & $\ldots$ & 0.7 & 0.5 & 14 \\
\hline
\end{tabular}

refer to short bursts of activity, say of quarter of an hour's duration. Estimates for a fulllength game including rest pauses would amount to less. Therefore in very rough terms, the total for the day's sport is $200 \mathrm{kcal}$. for the average player, and $150 \mathrm{kcal}$. for the average diarist. Alternative activities, if there had been no sport, would have cost at least $1 \frac{1}{2} \mathrm{kcal} . / \mathrm{min}$. Thus it appears likely that sport accounted additionally for an energy expenditure of $120 \mathrm{kcal}$. a day, and made a corresponding demand on the energy supplied by the average soldier's ration.

\section{Injuries Due to Sport}

In the ten years from 1952 to 1961 , the average annual rate of admissions to medical units, for all causes of injury, was 44 per 1,000 men. There were four major groups of admissions: traffic accidents $(8$ per 1,000$)$; knocks, cuts etc., and including burns ( 6 per $1,000)$ : falls etc. $(9$ per 1,000$)$; sport $(9$ per 1,000). In the United Kingdom the rates were all about $\frac{3}{4}$ of these. These admission rates are related to the numbers of soldiers serving. Another way is to relate them to the periods at risk, obtained from Table 1. Expressing the result as the number of injuries per 500,000 periods in 1962 we get a rate for each major theatre to contrast with the injury rate related to strength. The ratio between them gives an estimate of the periods played during a whole year by the average soldier (including non-players, and non-diarists), as shown in Table 7.

Table 7

Sports injuries in major theatres in 1962

\begin{tabular}{|c|c|c|c|c|c|c|c|}
\hline $\begin{array}{l}\text { U.K. } \\
\text { BAOR } \\
\text { Near East } \\
\text { Far East }\end{array}$ & $\begin{array}{c}\cdots . \\
\cdots \\
\cdots \\
\cdots \\
\cdots\end{array}$ & $\begin{array}{l}\cdots . . \\
\cdots . . \\
\cdots . . \\
\ldots . .\end{array}$ & $\begin{array}{l}\ldots . . \\
\ldots . \\
\ldots . \\
\ldots .\end{array}$ & $\begin{array}{l}\cdots \\
\cdots . . \\
\cdots \\
\cdots\end{array}$ & $\begin{array}{c}\text { Per } 500,000 \text { periods } \\
51 \\
84 \\
51 \\
50\end{array}$ & $\begin{array}{c}\text { Per } 1,000 \text { men } \\
7.5 \\
11.3 \\
10.9 \\
10.3\end{array}$ & $\begin{array}{c}\text { Periods per man } \\
74 \\
67 \\
107 \\
103\end{array}$ \\
\hline All theatres & $\ldots$ & $\ldots$. & $\ldots$ & $\ldots$. & 58 & 9.2 & 79 \\
\hline
\end{tabular}

Although the injuries per $\frac{1}{2}$ million periods in the Near and Far East were similar to the rate in the U.K., the amount played per man was higher, so that the combined effect was a higher rate of injury per serving soldier. (Swimming accounted for much of the extra 
sport played, but not necessarily for the extra injuries). BAOR also had a higher rate per 1,000 strength than the U.K, but the cause lay in a higher rate per $\frac{1}{2}$ million periods, not in the amount played. Part of the explanation for BAOR's higher rate may lie in the age distribution in that Command.

Table 8 gives an age breakdown of injury rates related to days when sport was played (not periods), as well as to strength, and deduces the days played per man.

Table 8

Sports injuries by age in 1962. All theatres

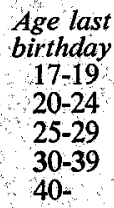

$\begin{array}{cc}\text { Per } 500,000 & \text { Per } 1,000 \text { men } \\ \text { days at risk } & 13.2 \\ 90 & 11.7 \\ 92 & 8.6 \\ 60 & 3.8 \\ 30 & 1.0\end{array}$

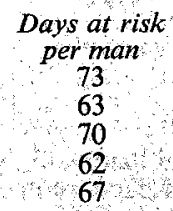

There is no clear trend in the days at risk per man, because although there were fewer old players, they played rather more often. The whole of the decreasing trend of injuries per 1,000 strength with age is associated with the lower risk when sports were played.

The injuries attributed to each sport are known, although a major assumption is that injuries due simply to "football" connote association football. Support is given to this by the diagnoses found in a sample where $34 \%$ of the "football " injuries were sprains and strains of the knee and leg, compared with $35 \frac{1}{2} \%$ where soccer was specified and $19 \frac{1}{2} \%$ for rugger injuries.

Soccer is responsible for half of the injuries and rugger for a smaller, though substantial number, but it is impossible to tell from this whether one sport is more hazardous than another, or is merely played more commonly. Wynn Parry (1956) obtained a higher proportion $(84 \%$ ) of association football injuries among patients in the Royal Air Force referred to a Rehabilitation Unit, and for injuries requiring this type of treatment he concluded that soccer had a higher degree of risk than rugger. However, his estimate that $2 \frac{1}{2}$ to 3 times as much soccer was played is essential in reaching the conclusion, and no evidence is given in its support.

\section{Injuries Related to the Amount of Sport Played}

We can now draw together the estimates of the numbers playing each sport, and the injuries resulting, so that the hazard can be determined for each one. The numerator is the number of injuries at each sport resulting in admission to a medical unit in 1962 . The denominator is the number of periods played, estimated at 500 times the number reported in the Survey, plus a correction for the non-responders (paragraph 2a). The ratios are expressed in Table 9 as injuries per 100,000 periods at risk.

Ski-ing and rugby football head the list with the highest rates of injury, followed by association football and then boxing - played under Army conditions. The sports listed in the table are the only ones that were severally coded from the inpatient medical records, and it is not possible to say, without investigating further, where other activities such as golf would figure in the table. 
Table 9

Injuries at each sport in 1962. All theatres

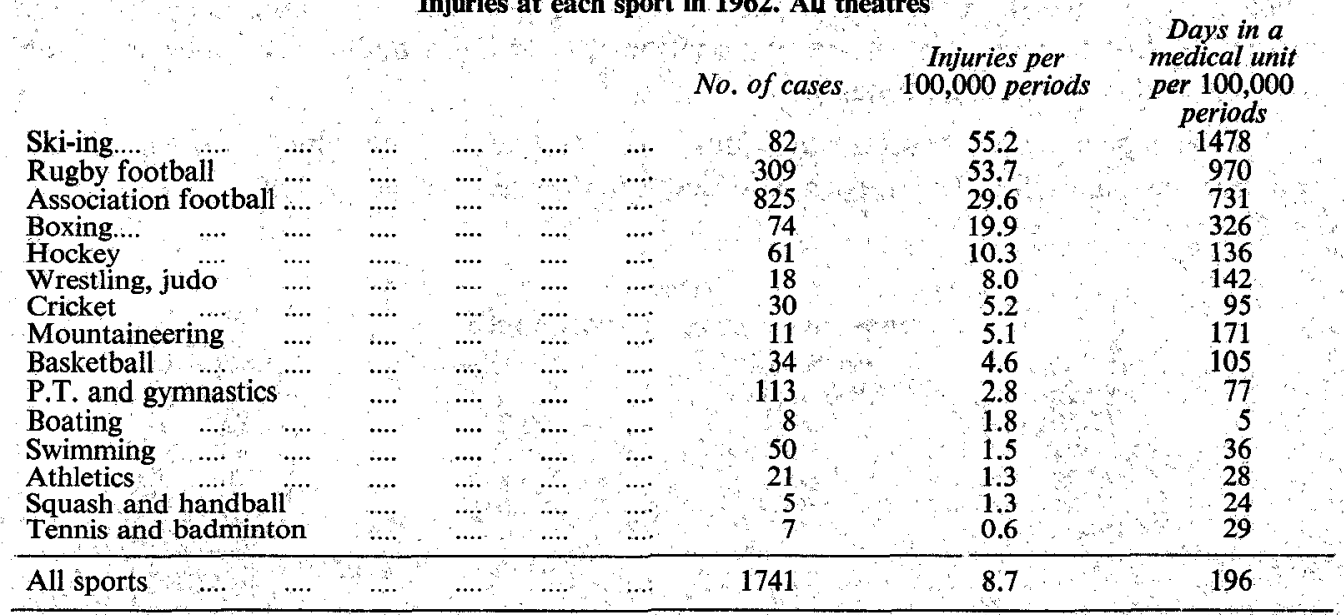

Note: duration of stay includes both the day of admission to a medical unit, and the day on which the patient was discharged.

The low rate of injuries for swimming is an indication that the high overall injury rate in warm climates is not linked with the popularity of this particular activity. Referring back to Table 7 the highest rate for all sports combined occurred in BAOR. This is true for a number of the important individual sports also, but there are exceptions. Owing to the small numbers involved when individual sports are broken out for each Command, only selected results will be given, and all non-temperate areas will be grouped together in Table 10.

Table 10

Selected rates of injury per 100,000 periods played, in main theatres, 1962

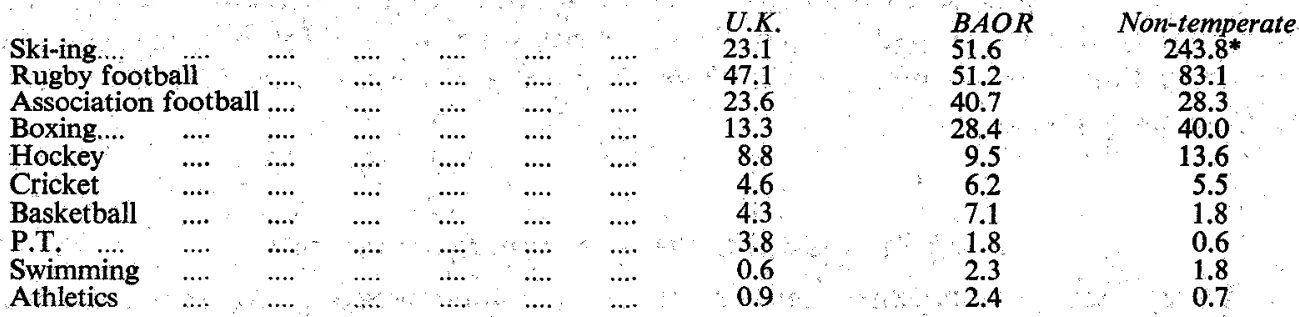

*Note: this is based on very few periods played. It is possible that some injuries are attributable to training rather than sport.

Apart from P.T., BAOR had higher injury rates than the U.K. for every sport listed, but these were in turn exceeded in the non-temperate theatres for ski-ing, rugger, boxing and hockey. The causes of the variation might be manifold: games might be better controlled in the U.K., where many would be played by young soldiers under close supervision, grounds might be softer in our moist climate; the tempo of games may differ according to the humidity; temperatures may affect resilience to injury. However, the variation from these causes is small in comparison with the differences between sports. 
Finally, we turn our attention to boxing, and note that the fractures of the upper limb are chiefly $(79 \%)$ fractures of metacarpal bones. The area of greatest concern is the head; $33 \%$ of the injuries to the head were fractures of face bones, and $46 \%$ were concussion. (The precise topography of the blows can be gathered from a study of the case-notes a series of 155 cases over the years 1952 and 1953 gave 45 injuries to the nose, 42 to the jaw, 15 to the ear and 10 to the eye; the left side of the head, being more often presented to the attack, was more often struck). There is, of course, no evidence from this kind of investigation of any untoward subclinical effects. Therefore our finding that boxing is not apparently the most hazardous of sports is not conclusive. There is, nevertheless, sufficient scope for reducing the hazards in more sports than one, and it is to be hoped that these findings may contribute to the better conduct and safer practice of sport, the modification of rules, the improvement of equipment, and the development of appropriate protective wear. Batting pads, shin guards, gum shields, riding hats, boxing gloves, scrum caps, fencing masks and other forms of protection already exist. Is there any reason why, for instance, a head guard should not be worn in a boxing match as well as for sparring?

\section{Summary}

A SAMPLE survey of the sport played in the Army was based on the diaries kept for a month by soldiers selected at random and serving in theatres both at home and overseas. Estimates are obtained of the amount of each sport played, together with seasonal patterns and the influence of climate. Other factors examined are rank and age, the physique of players and the expenditure of effort. The most commonly played sport was association football, the numbers being of the same order as those who did PT Swimming was very popular, especially in the warmer climates.

Injuries at sport are investigated, and related to the periods played In this way the degrees of risk are assessed, and it is found that ski-ing and rugby football were the most hazardous of the sports considered. Association football and boxing come next, in terms of the criterion adopted. The severity and nature of the injuries are also investigated.

\section{REFERENCES}

EDHolM, O. G. Fletcher, J. G., WidDowson, E. M. and McCANCE, R. A. (1955) "The energy expenditure and food intake of individual men." Brit. J. Nutr. 9, 286-300.

LLOYD, K. (1959). "Some hazards of athletic exercise." Proc. R. Soc. Med, 52, 151-157.

PASSMORE, R. and DURNIN, J V. G. A. (1955). "Human energy expenditure" Physiol, Rev, 35, 801-840. TANNER, J. M. (1964). "The physique of the Olympic Athlete."Allen and Unwin, London.

WYNN PARRY, C B. (1956). Discussion on injuries in sport:" Proc. R. Soc. Med 49, 446451. 